\title{
Two Deaths and a Birth: Reminiscing and Rehashing Principles in Biomedical Ethics
}

\author{
Michael A. Ashby • Leigh E. Rich
}

Received: 16 December 2013 / Accepted: 5 January 2014

(C) Springer Science+Business Media Dordrecht 2014

Two anniversaries and one notable death have been observed in the last two months of 2013: the 50th anniversary of the assassination of U.S. President John F. Kennedy, the centenary of the birth of French Algerian Nobel Prize-winning author and philosopher Albert Camus, and the passing from this world of South African social activist and President Nelson Mandela. These three lives have left indelible marks on the human experience in myriad ways, but each, as a defining characteristic, placed an emphasis on the necessity of individual moral responsibility.

In his June 1963 commencement address to the graduates of American University in Washington, D.C., just five months before he died, JFK emphasized the importance of the individual ethical responsibility to work for peace. "[E]very graduate of this school, every thoughtful citizen who despairs of war and wishes to bring peace," he intoned, "should begin by looking

M. A. Ashby

Palliative Care Service, Royal Hobart Hospital, Southern Tasmania Area Health Service, and School of Medicine, Faculty of Health Sciences, University of Tasmania, 1st Floor, Peacock Building, Repatriation Centre, 90 Davey Street, Hobart, TAS 7000, Australia e-mail: michael.ashby@dhhs.tas.gov.au

L. E. Rich $(\bowtie)$

Department of Health Sciences (Public Health), Armstrong

Atlantic State University,

11935 Abercorn Street, University Hall 154F, Savannah, GA

31419, USA

e-mail: leigh.rich@armstrong.edu inward - by examining his own attitude toward the possibilities of peace, toward the Soviet Union, toward the course of the cold war and toward freedom and peace here at home" (Kennedy 1963, ๆ10). This speech is argued to have been one of the most important made by a president in the 20th century (see Clarke 2013 and Sachs 2013), as it gave the signal to Soviet leader Nikita Khrushchev for a common disarmament goal and opened the door for the United States, the Soviet Union, and the United Kingdom to initiate the nuclear test ban treaty (United Nations Office for Disarmament Affairs 1963; Etzioni 1967).

The American University address built on a liberal construct that was immortalized in JFK's 1961 inaugural address: "ask not what your country can do for youask what you can do for your country" (Kennedy 1961, 926). This was liberal, of course, in a British and not an American sense, in its purer political science meaning of supremacy of the individual over the collective or crowd, in the Mill tradition rather than Marx! So for Kennedy (and his speechwriter Ted Sorensen), the appeal in the oft-quoted speech is to the individual citizen (of the United States and the world) as a moral agent. Philosophically, this important exhortation should come as no surprise to anyone, then or now. There is no doubt, though, that most people feel powerless in "big picture" global political matters, so it may in fact come as "news" to most of us that we can change anything, no matter what we may first think or believe.

As anthropologist Margaret Mead once quipped, “[n] ever doubt that a small group of thoughtful committed individuals can change the world" (cited in Bowman- 
Kruhm 2003, 141). On the other hand, as John Stuart Mill warned:

Bad men need nothing more to compass their ends, than that good men should look on and do nothing. He is not a good man who, without a protest, allows wrong to be committed in his name, and with the means which he helps to supply, because he will not trouble himself to use his mind on the subject (cited in Fitzpatrick 2010, 155).

Thus, our errors of omission can be as blameworthy as our misdeeds. This is a sentiment that the writings of Albert Camus support. In an absurd world, all the ordinary person can do is rebel, and that rebellion defines personhood by giving meaning, the only meaning to be had in such a world: Where "l'homme révolté" exists (Camus 1956), he (or she) constructs a meaning of life through individual moral agency, one that is not externally given. (Nonetheless, it would be hard to argue for even the most ardent existentialist that individual moral agency is not shaped, to some degree at least, by external forces such as society and religion.)

Although Camus was famously misquoted at a 1957 Stockholm press conference after his Nobel Prize award as saying that "I believe in justice, but I will defend my mother before justice," this perceived prioritization of the personal over a higher communal standard is not what he meant. Rather, he was trying to speak to the unfairness of random terrorist acts on the Algiers tramway system on which his mother (among other innocent bystanders) might be travelling. He condemned violence on both sides and longed for a peaceful coexistence of French and Algerians that sadly never happened. Instead, independence was bought at the cost of mutual barbarity (see Camus 2013). This episode, however, illustrates the tension in moral reasoning between the personal and the public - and individual and social values - and that affective, biological, and social loyalties guide us at least as often as more abstracted ethical principles.

Although there is no official symposium or theme in this issue of the Journal of Bioethical Inquiry, each of the papers speaks to this tension and, in their own way, calls for more in-depth and nuanced explorations of the four biomedical principles set forth by Tom L. Beauchamp and James F. Childress in 1979. The first two papers, "Market Liberalism in Health Care: A
Dysfunctional View of Respecting 'Consumer' Autonomy” by Michael A. Kekewich (2014) and "Anorexia Nervosa: The Diagnosis: A Postmodern Ethics Contribution to the Bioethics Debate on Involuntary Treatment for Anorexia Nervosa" by Sacha Kendall (2014), take on what is often (especially in the United States) assumed to be the "first" principle: autonomy. Kekewich argues that the long and often untoward history of paternalism in both medicine and clinical research has given paternalism a bad name and that, rather than throwing out the baby with the bathwater and letting baby fend as an abandoned consumer in an increasingly medical marketplace, "some form of paternalism is required in any meaningfully therapeutic relationship" (Kekewich 2014, under "Abstract"). Kendall, on the other hand, examines the ethical dilemmas and even absurdities surrounding involuntary treatment for anorexia nervosa. She emphasizes that the medically constructed diagnosis of anorexia nervosa tends to reaffirm professional knowledge and values and unsurprisingly "justifies" paternal exercises of treatment adherence, while patients are placed in a no-win situation where "competency" and thus "autonomy" can be demonstrated only by conforming. Whether deemed "competent" or not, the end result is the same, and "anorexia nervosa: the diagnosis" inherently limits the identities of persons suffering from the disease. Carney (2014) and Ryan and Callaghan (2014), leading scholars in this important area, also offer commentaries on Kendall's paper.

Discussions of paternalism and autonomy are no strangers to the subject of procreation and, more recently, assisted reproductive techniques (ART). In "Making Sense of Child Welfare When Regulating Human Reproductive Technologies," McMillan (2014) revisits the intent and consequences of ART-related laws to examine the idea that some policy-makers and bioethicists have proposed (or opposed) of a "best interests" or "child welfare" test. McMillan finds common ground, rather than a push and pull, between liberty and beneficence in a rights-based approach, concluding that "relevant policy can be interpreted as requiring those wishing to exercise their procreative liberty to have a reasonable plan to care and nurture any resulting child, thereby respecting the internal preconditions of that liberty" (McMillan 2014, under "Abstract”).

Similarly, Mitchell Lawlor and Ian Kerridge in "Understanding Selective Refusal of Eye Donation: Identity, Beauty, and Interpersonal Relationships" (2014) explore reasons why family members choose not to donate 
corneal tissue upon the death of loved ones, even while allowing the donation of other tissues and organs. They demonstrate how the tension between beneficence and nonmaleficence bubbles to the surface with regard to the eyes: Refusal to donate is "related to concerns about disfigurement," "the role of eyes in memory and communication," and "a potential adverse change in the ongoing relationship with the deceased, even in death" (Lawlor and Kerridge 2014, under "Abstract"). These concerns, moreover, trump awareness of the growing need for and the benefits of corneal transplantation. (See also Joan Didion's 2005 text, at pages 443-444, where she describes how what might be called her early grief work was centered around bringing back her deceased husband, underscoring how those grieving often do not get rid of clothes [or corneas] because the real project is to bring the dead person back.)

The principles of autonomy, beneficence, and nonmaleficence also come to play in Brad Partridge's paper, "Dazed and Confused: Sports Medicine, Conflicts of Interest, and Concussion Management" (2014), which highlights the ethical dilemmas inherent in return-to-play decisions and policies in professional football. While coaches and teammates - and even the injured individuals themselves - may have vested interests in seeing players return to the field as soon as possible, team doctors are caught between professional duties of care and obligations to their employers. Likewise, Ryan Essex in "Human Rights, Dual Loyalties, and Clinical Independence: Challenges Facing Mental Health Professionals Working in Australia's Immigration Detention Network" (2014) examines issues of nonmaleficence as well as justice, illustrating the potential conflicts of interest for practitioners working with detained populations and asylum seekers and calling for "larger systemic change"-with those who work on the frontlines in the detention environment leading the way forward. Lastly, Chris Kaposy in "Drugs, Money, and Power: The Canadian Drug Shortage" (2014) appeals to health care organizations and governments to live up to their obligation to secure pharmaceutical supplies and prevent exposing patients to resource scarcity.

In keeping with this ad hoc "four principles" theme, the JBI's "Reviews" section also offers evaluations of Benevolence by Cynthia Holz (Smith 2014), Against Fairness by Stephen T. Asma (Menzel 2014), and the films Tales From the Organ Trade (Bramstedt 2014b) and Silver Linings Playbook (Bramstedt 2014a).
In considering paternalism and foundational principles of biomedical ethics, this issue meditates on the dangers of infringing on and diminishing the power and place of individual moral agency. Anything that overlays and inhibits the flourishing and action of human conscience must have very good reasons to justify itself, a sort of "force majeure" as it is known in the law. The papers and reviews herein take this charge seriously, scrutinizing both the reasoning and implications of doing (or not doing) so but also offering new perspectives on "old" problems that may, in fact, change how we have come to see them.

When reminiscing and rehashing, there is a risk, of course, of muddying our memories rather than enabling more authentic understandings. This is evident when the death of someone famous generates a broad-sweeping media grief or even a hagiography that idealizes and idolizes a human life. The goal, however, whether in this issue, in bioethics, or in general is to seek clarity through reflection and continue to learn from our triumphs and tragedies. The death of Nelson Mandela teaches such a lesson. Mandela himself likely would be chagrined at some of the "picturesque" reporting of his life and legacy (compare how he once reportedly told French politician Laurent Fabius that he was a "dur," a toughie, when he was young!). The undoubted titanic achievements of Mandela's life are undisputed, but there were, too-as with any human (and even those nearly superhuman)-failures in leadership and government that will have to await the passage of time and historical analysis. What cannot be questioned is the moral authority Mandela acquired through 27 years in captivity for his beliefs and for fostering a peaceful transition from apartheid, embodied by the remarkable South African Truth and Reconciliation Commission. These are both moral acts by a single man who did not set out with great power but ultimately gained it through selfsacrificial acts of persistent defiance. This is real moral courage, where life is given for cause and personal interests are set aside. (There are costs, too, for family members, who missed out on life with a father and husband, as several revealing family interviews have documented. See, for example, Dixon 2013; HunterGault 2013; The Associated Press 2013).

So one recent death that has captured the present world in moral thrall, one now-distant death within living memory but about to pass into history as the global witnesses die, and an obscure birth a century ago in French North Africa of an eventual literary titan 
illuminate, in an effective way, the nature of personal responsibility and the power and duty of moral agency. Whatever we may think of the global, media-saturated treatment of such events (often for gain), there are important learnings in reflecting on the lives of such giant — but still individual — men and women and what changes can be birthed when we trouble ourselves to commit thought and will to subjects that matter.

\section{References}

Beauchamp, T.L., and J.F. Childress. 1979. Principles of biomedical ethics. New York: Oxford University Press.

Bowman-Kruhm, M. 2003. Margaret Mead: A biography. Westport: Greenwood Press.

Bramstedt, K.A. 2014a. Review of Silver Linings Playbook, written and directed by David O. Russell. Journal of Bioethical Inquiry 11(1). doi:10.1007/s11673-013-9500-5.

Bramstedt, K.A. 2014b. Review of Tales From the Organ Trade, written and directed by Ric Esther Bienstock. Journal of Bioethical Inquiry 11(1). doi:10.1007/s11673-013-9502-3.

Camus, A. 1956. The rebel: An essay on man in revolt. Trans. A. Bower. New York: Alfred A. Knopf. Originally published as L'homme révolté (Paris: Librairie Gallimard, 1951).

Camus, A. 2013. Algerian chronicles. Ed. A. Kaplan, trans. A. Goldhammer. Cambridge, MA: The Belknap Press. Originally published as Chroniques algériennes (Paris: Editions Gallimard, 1958).

Carney, T. 2014. The incredible complexity of being? Degrees of influence, coercion, and control of the "autonomy" of severe and enduring anorexia nervosa patients. Journal of Bioethical Inquiry 11(1). doi:10.1007/s11673-013-9506-z.

Clarke, T. 2013. JFK's last hundred days: The transformation of a man and the emergence of a great president. New York: The Penguin Press.

Didion, J. 2005. The year of magical thinking. New York: Alfred A. Knopf.

Dixon, R. 2013. Nelson Mandela's daughter shares memories of her father. Los Angeles Times, December 9. http://www. latimes.com/world/worldnow/la-fg-wn-nelson-mandela-lastday-20131209,0,2019041.story\#ixzz2pei0wb6U.

Essex, R. 2014. Human rights, dual loyalties, and clinical independence: Challenges facing mental health professionals working in Australia's immigration detention network. Journal of Bioethical Inquiry 11(1). doi:10.1007/s11673013-9493-0.

Etzioni, A. 1967. The Kennedy experiment. The Western Political Quarterly 20(2, Part 1): 361-380.
Fitzpatrick, J.R. 2010. Starting with Mill. London and New York: Continuum International Publishing Group.

Hunter-Gault, C. 2013. Nelson Mandela, the father. The New Yorker, December 5. http://www.newyorker.com/online/ blogs/newsdesk/2013/12/nelson-mandela-south-africasfather.html.

Kaposy, C. 2014. Drugs, money, and power: The Canadian drug shortage. Journal of Bioethical Inquiry 11(1). doi:10.1007/ s11673-013-9494-z.

Kekewich, M.A. 2014. Market liberalism in health care: A dysfunctional view of respecting "consumer" autonomy. Journal of Bioethical Inquiry 11(1). doi:10.1007/s11673-013-9492-1.

Kendall, S. 2014. Anorexia nervosa: The diagnosis: A postmodern ethics contribution to the bioethics debate on involuntary treatment for anorexia nervosa. Journal of Bioethical Inquiry 11(1). doi:10.1007/s11673-013-9496-x.

Kennedy, J.F. 1961. Inaugural address, 20 January 1961. John F. Kennedy Presidential Library and Museum. http://www. jfklibrary.org/Asset-Viewer/BqXIEM9F4024ntF17SVAjA. aspx.

Kennedy, J.F. 1963. Commencement address at American University, June 10, 1963. John F. Kennedy Presidential Library and Museum. http://www.jfklibrary.org/AssetViewer/BWC7I4C9QUmLG9J6I8oy8w.aspx.

Lawlor, M., and I. Kerridge. 2014. Understanding selective refusal of eye donation: Identity, beauty, and interpersonal relationships. Journal of Bioethical Inquiry 11(1). doi:10.1007/ s11673-013-9497-9.

McMillan, J. 2014. Making sense of child welfare when regulating human reproductive technologies. Journal of Bioethical Inquiry 11(1). doi:10.1007/s11673-013-9495-y.

Menzel, P.T. 2014. Review of Against Fairness, by Stephen T. Asma. Journal of Bioethical Inquiry 11(1). doi:10.1007/ s11673-013-9505-0.

Partridge, B. 2014. Dazed and confused: Sports medicine, conflicts of interest, and concussion management. Journal of Bioethical Inquiry 11(1). doi:10.1007/s11673-013-9491-2.

Ryan, C.J., and S. Callaghan. 2014. Treatment refusal in anorexia nervosa: The hardest of cases. Journal of Bioethical Inquiry 11(1). doi:10.1007/s11673-013-9498-8.

Sachs, J.D. 2013. To move the world: JFK's quest for peace. New York: Random House.

Smith, G.C. 2014. Review of Benevolence, by Cynthia Holz. Journal of Bioethical Inquiry 11(1). doi:10.1007/s11673013-9504-1.

The Associated Press. 2013. Nelson Mandela's daughter: "He was not there as a father." CBS News, May 28. http://www. cbsnews.com/news/nelson-mandelas-daughter-he-was-notthere-as-a-father/.

United Nations Office for Disarmament Affairs. 1963. Treaty banning nuclear weapon tests in the atmosphere, in outer space and under water. http://disarmament.un.org/treaties/t/ test_ban. 